\title{
PERLINDUNGAN HUKUM TERHADAP PT. PEGADAIAN (PERSERO) DALAM HAL BARANG JAMINAN GADAI BUKAN MILIK DEBITUR
}

\author{
Oleh : \\ Ida Ayu Gede Narasanti ${ }^{1}$
}

\begin{abstract}
Pawnshop is a State-Owned Enterprise (SOE). Pawnshops give credit to the community by Quick and Safe Credit (KCA). Giving credit of course must be accompanied by the provision of a guarantee as repayment of loans granted to the debtor. The collateral is in the form of moving objects. The collateral can be derived from belonging ofa debtor or the one that does not belong to the debtor. However, if the collateral does not belong to the debtor has problems; the pawnshop can suffer losses so it should receive legal protection. The issues raised were: Firstly; about how arrangements regarding legal protection against PT. Pegadaian (Persero) in terms of the collateral pledge not belong to the debtor. Second; about what the legal settlement isif the objectdoes not belong to the debtor's pledge collateral. The research method used is the empirical method whose research object of study includes the implementation of normative legal provisions in action / in abstracto on each legal event taken place in the community (in concreto). The results showed that the legal protection was given to Pawnshop if collateral pledge did not belong to the debtor in general which can be found in Article 1131 and Article 1132 of the Civil Code which states that all the materials of a debtor becomes the liability of all individual agreement, the material becomes joint collateral for all people who lend him some money, the sales revenue is divided according to the balance and the size of the receivables unless there are legitimate reasons to take precedence. Settlement of the object that did not belong to the debtor's pledge came from the report loss from a pawn object owner who wanted to reclaim the object that wasused as collateral with regard to deadline to reclaim, i.e. not more than 3 years since the loss or theft of items used as collateral. The owner of the pawn object can take legal procedures by making a report to the police so that it can proceed to court.
\end{abstract}

Keywords : legal protection, goods, guarantee, pledge

\begin{abstract}
Abstrak
Pegadaian adalah Badan Usaha Milik Negara (BUMN). Pegadaian memberikan kredit kepada masyarakat dengan cepat dan Aman Kredit (KCA). Pemberian kredit tentu harus disertai dengan pemberian jaminan sebagai pembayaran kembali pinjaman yang diberikan kepada debitur. agunan berupa benda bergerak. agunan bisa berasal dari milik ofa debitur atau salah satu yang bukan milik debitur. Namun, jika agunan bukan milik debitur memiliki masalah; pegadaian dapat menderita kerugian sehingga harus mendapat perlindungan hukum. Isu yang diangkat adalah: Pertama; tentang bagaimana pengaturan

Mahasiswa Magister Ilmu Hukum Universitas Udayana, Denpasar, Bali. Alamat Jl. Cekomaria Melati Indah No.6 Denpasar, e-mail: naraswann@gmail.com
\end{abstract}


mengenai perlindungan hukum terhadap PT. Pegadaian (Persero) dalam hal janji agunan bukan milik debitur. Kedua; tentang apa penyelesaian hukum ISIF yang objectdoes bukan milik debitur jaminan gadai. Metode penelitian yang digunakan adalah metode empiris yang penelitiannya objek penelitian meliputi pelaksanaan ketentuan hukum normatif dalam tindakan / di abstracto pada setiap acara hukum terjadi di masyarakat (in concreto). Hasil penelitian menunjukkan bahwa perlindungan hukum diberikan kepada Pegadaian jika agunan janji bukan milik debitur secara umum yang dapat ditemukan dalam Pasal 1131 dan Pasal 1132 KUHPerdata yang menyatakan bahwa semua bahan dari debitur menjadi tanggung jawab semua persetujuan individual, material menjadi jaminan bersama bagi semua orang yang meminjamkan uang, pendapatan penjualan dibagi sesuai dengan keseimbangan dan ukuran piutang kecuali ada alasan yang sah untuk didahulukan. Penyelesaian dari objek yang bukan milik janji debitur berasal dari hilangnya laporan dari pemilik gadai objek yang ingin merebut kembali objek yang wasused sebagai jaminan sehubungan dengan tenggat waktu untuk merebut kembali, yaitu tidak lebih dari 3 tahun sejak kehilangan atau pencurian item yang digunakan sebagai jaminan. Pemilik objek gadai dapat mengambil prosedur hukum dengan membuat laporan ke polisi sehingga bisa melanjutkan ke pengadilan.

Kata Kunci: perlindungan hukum, barang, jaminan, gadai

\section{PENDAHULUAN}

\subsection{Latar Belakang}

Upaya pemerintah dalam menghadapi tantangan era globalisasi memerlukan berbagai langkah alternatif yang bertujuan untuk memberikan kontribusi menjawab tantangan perekonomian ke depan. Salah satunya adalah mengupayakan agar produk Indonesia mampu bersaing dengan produk luar yang masuk Indonesia ataupun di pasar internasional. Menghadapi kendala tersebut,Pemerintahharusbekerjakeras untuk menangani kondisi ini dengan cepat, disertai dengan semangat dan dukungan masyarakat untuk mencari jalan keluar dari krisis ekonomi sehingga mampu meningkatkan efisiensi ekonomi. Dalam konteks tersebut langkah alternatif yang dapat ditempuh diantaranya adalah memaksimalkan peran BUMN melalui format baru yang efisien. BUMN di Indonesia bergerak hampir diseluruh aspek ekonomi. Kemampuan BUMN untuk menjadi penggerak efisiensi nasional sangat diharapkan sehingga peran sebagai agen pembangunan mampu tercapai. Salah satu BUMN yang berperanan dalam perkembangan ekonomi kerakyatan adalah Pegadaian, yang kini berbentuk hukum perseroan menjadi PT. Pegadaian (Persero) (selanjutnya disebut Pegadaian).

Perubahan status badan hukum Pegadaian dari Perum ke PT diharapkan dapat memacu dan memicu kinerja Pegadaian lebih ekspansif lagi sehingga kemampuan permodalan yang dimiliki Pegadaian Lebih kuat dan lebih besar lagi untuk melayani nasabahnya. ${ }^{2}$ Secara umum 
alasan perubahan badan hukum oleh Pegadaian karena adanya pasar bisnis micro finance di Indonesia yang sangat besar sehingga peluang bisnis ini harus ditangkap oleh Pegadaian dengan kemampuan dan kapasitas yang lebih besar. Selain itu citra Pegadaian di mata nasabah semakin baik dan mengakar sehingga diharapkan nasabah tetap loyal dan bahkan semakin bertambah loyal dengan keberadaan Pegadaian yang berstatus persero.

Pegadaian merupakan alternatif bagi masyarakat khususnya kalangan menengah ke bawah untuk melakukan pinjaman berdasarkan hukum gadai dengan prosedur pelayanan yang mudah, aman dan cepat atau biasa disebut KCA (Kredit Cepat dan Aman). Pegadaian merupakan salah satu BUMN di Indonesia yang inti dari usahanya adalah bidang jasa berupa penyaluran kredit/pinjaman kepada mayarakat berdasarkan pada hukum gadai. $^{3}$ Pegadaian semakin diminati masyarakatnya karena keberadaanya memang sangat diperlukan sebagai tempat untuk mendapatkan pendanaan secara cepat dan mudah. Bisnis utama Pegadaian adalah KCA (Kredit Cepat Aman). Mudah,murah, cepat, aman nyaman dan berkualitas. Inilah prosedur yang diterapkan Pegadaian mulai dari tahap pengajuan pinjaman pencairan sampai pelunasan. Kalau sudah jatuh tempo tapi belum dapat dilunasi maka Pegadaian memberi kesempatan kepada si nasabah untuk memperpanjang pinjamannya.

Warta Pegdaian, edisi 161/tahun xxiii/2013.
Demikian seterusnya Pegadaian memberikan kemudahan kepada para nasabah dalam menebus barang atau memperpanjanggadaibarangnyaUntuk menjaga agar tidak sampai dilelang, Pegadaian selalu mengingatkan kepada si nasabah baik melalui surat maupun telepon agar segera membayar sebelum jatuh tempo. namun apabila nasabah bersangkutan tetap tidak melakukan kewajiban pembayaran, maka barang gadainya terpaksa dilelang. ${ }^{4}$

Hubungan hutang piutang diantara debitur dengan kreditur biasanya disertai dengan jaminan. Jaminan yang digunakan dapat berupa uang dan dapat berupa orang. Dalam permasalahan ini yang akan ditekankan adalah hubungan hutang piutang dengan menggunakan jaminan benda. Dengan keberadaan jaminan ini, maka kreditur mempunyai hak atas benda jaminan sebsagai pelunasan piutangnya apabila debitur tidak mampu untuk membayar hutangnya. Benda jaminan itu dapat berupa benda bergerak dan dapat berupa benda tidak bergerak. Apabila benda yang digunakan sebagai jaminan adalah benda bergerak, maka hak atas benda jaminan itu disebut "gadai". 5

Prinsip atas jaminan gadai yakni saat pemberi gadai menyerahkan barang gadai kepada pihak Pegadaian,

4 Edy Sasmito, dkk, 2010, Pegadaian dan rakyat kecil, IPB Pers, Bogor, hlm.54-55.

Abdul Kadir Muhammad, 2000, Hukum Perdata Indonesia, PT Citra Aditya Bakti, Bandung, (Selanjutnya disebut Abdul Kadir Muhammad I) hlm. 170. 
maka kekuasaan atas benda gadai tersebutberalihkepadapihakPegadaian yang selanjutnya disebut pihak pemegang gadai. Penguasaan terhadap benda gadai tersebut berlangsung sampai debitur atau nasabah melunasi hutangnya. Akan tetapi, hak menguasai barang itu tidak meliputi hak untuk memakai, menikmati atau memungut hasil barang yang dipakai sebagai jaminan. $^{6}$

Secara normatif, syarat jaminan yang dapat diterima diPegadaianadalah barang bergerak yang merupakan milik nasabah sendiri serta nasabah menjamin bukan merupakan hasil dari kejahatan, tidak dalam obyek sengketa dan atau sita jaminan (Surat Bukti Kredit Pegadaian), hal ini mengacu pada ketentuan pasal 1977 Kitab Undang - Undang Hukum Perdata (selanjutnya disebut KUHPerdata) yang pada prinsipnya menyatakan bahwa siapa yang menguasai benda bergerak dianggap sebagai pemiliknya. Penyerahan barang jaminan dari nasabah ke Pegadaian menimbulkan peralihan hak sesuai dengan ketentuan bahwa, pemberian barang sebagai jaminan berarti pelepasan atas sebagian kekuasaan daripada barang tersebut. ${ }^{7}$

Hal ini diatur dalam pasal 1155 KUHPerdata, yang pada

Sri Soedewi Masjchocn Sofwan f, 2000, Hukum Perdata Hukum Benda, Cet. V, Liberty, Yogyakarta, hlm. 98.

$7 \quad$ R Subekti, 1982, Jaminan - Jaminan Untuk Pemberian Kredit Menurut Hukum Indonesia, Alumni, Bandung, (selanjutnya disebut R. Subekti I) hlm. 17. intinyamenentukan bahwa apabila pihak pemberi gadai tidak melaksanakan kewajibannya atau wanprestasi paka pihak penerima gadai berhak melakukan penjualan atas jaminan gadai dengan tujuan untuk mengambil pelunasan atas pokok pinjaman, dan biaya atas penjualan jaminan tesebut." ${ }^{8}$ Namun pada prakteknya, sering terjadi permasalahan dimana barang yang dijaminkan bukan milik nasabah sendiri melainkan milik orang lain misalnya barang jaminan atas suruhan dan barang yang diperoleh secara melawan hukum dan memperolehnya secara tidak sah, ataupun cara lain yang dilarang oleh hukum.

Ketika barang yang dijaminkan bukan milik nasabah melainkan milik orang lain yang diperoleh secara melawan hukum maka muncul persoalan yang menyebabkan Pegadaian mengalami kerugian, baik berupa modal kerja maupun laba akibat barang jaminan yang diambil untuk disita kebanyakan tidak dikembalikan, lama dikembalikan ataupun dikembalikan rusak akibat penyitaan oleh Penyidik. Dari tahun 2010 sampai dengan 2014 dalam satu cabang pegadaian dalam kota dapat terjadi sengketa barang jaminan hingga tiga kasus. Tiap kasus bisa meliputi kuotasepuluhataulebihbarangjaminan yang disengketakan. Penyelesaian kasus pun tidak memerlukan waktu yang sedikit, karena memerlukan

$8 \quad$ Purwahid Patrik dan Karsadi, Op cit, hlm. 23 
waktu hingga mencapai putusan akhir dan pengembalian jaminan baru dapat dilakukan setelah putusan pengadilan ditetapkan. Hal ini tentu menyebabkan kerugian bagi finansial Pegadaian. Untuk itu perlu dilakukan penelitian bagi perlindungan hukum bagi Pegadaian dalam hal jaminan gadai bukan milik debitur . berdasarkan permasalahan yang telah diuraikan diatas, maka penulis tertarik untuk membahas lebih lanjut dalam tesis ini dengan mengangkat judul : Perlindungan Hukum Terhadap PT Pegadaian(Persero) Dalam Hal Barang Jaminan Gadai Bukan Milik Debitur.

Untuk itu menarik untuk dikaji, bagaimana perlindungan hukum terhadap PT. Pegadaian (PERSERO) dalam hal barang jaminan gadai bukan milik debitur.

\subsection{Perumusan Masalah}

1. Bagaimanakah pengaturan mengenai perlindungan hukum terhadap PT Pegadaian(Persero) dalam hal barang jaminan gadai bukan milik debitur?

2. Bagaimanakah penyelesaian hukum apabila barang jaminan gadai bukan milik debitur?

\subsection{Tujuan Penelitian}

Secara umum penelitian

ini bertujuan untuk mengkaji pengembangan ilmu hukum sehubungan dengan paradigmas science as a process (ilmu sebagai suatu proses). Paradigma ilmu tidak akan berhenti dalam penggaliannya atas kebenaran dalam bidang perlindungan hukum bagi PT.Pegadaian (Persero) dibidang perkreditan khususnya dalam hal jaminan gadai bukan milik debitur, dan untuk mengkaji Terwujudnya kepastian hukum berkaitan dengan penyelesaian sengketa kepemilikan jaminan gadai Sedangkan yang menjadi tujuan khusus adalah :

1. Untuk mengetahui pengaturan mengenai perlindungan hukum bagi PT Pegadaian (Persero) dalam hal barang jaminan gadai bukan milik debitur.

2. Untuk mengetahui penyelesaian sengketa terhadap barang jaminan gadai yang diagunankan pada PT Pegadaian (persero) bukan milik Debitur.

\section{METODE PENELITIAN}

Didalam penulisan tesis ini metode yang digunakan adalah jenis penelitian hukum empiris, yaitu suatu penelitian hukum yang objek kajiannya meliputi ketentuan dan implementasi dari suatu ketentuan hukum normatif (kodifikasi, Undang-Undang atau kontrak) secara in action/in abstracto terhadap peristiwa hukum yang senyatanya terjadi di masyarakat (in concreto $)^{9}$

Penelitian ini bersifat deskriptif, yaitu penggambaran secara tepat atas suatu keadaan, gejala, sifat daripada individu ataupun suatu kelompok

Abdulkadir Muhamad, 2004, Hukum dan Penelitian Hukum, Citra Aditya Bakti, Bandung, hlm. 134 
tertentu dan menemukan keberadaan hubungan antara suatu gejala dengan gejala lain dalam masyarakat. ${ }^{10}$

Dalam penelitian hukum empiris data dapat dibedakan menjadi 2 (dua) yaitu: Data primer, yang diperoleh dari penelitian ini dengan melakukan penelitian di PT. Pegadaian Persero Kanwil Denpasar, Bali. Penelitian ini dilakukan melalui wawancara terhadap informan serta terhadap responden yang berada pada lokasi penelitian dan data sekunder diperoleh melalui penelitian kepustakaan (Library Research) dengan menggunakan bahan-bahan hukum.

Pengolahan data adalah pengumpulan data yang diperoleh dari lapangan kemudian dirapikan sehingga dapat dipergunakan sebagai bahan analisa. ${ }^{11}$ Pengolahan data secara kulitatif yaitu dengan membandingkan data yang diperoleh dilapangan dengan datakepustakaandilakukan setelah data terkumpul sehingga akan diperoleh data yang menunjang penyelesaian prmasalahan empiris. Metode analisa deskriptif digunakan dalam proses analisa data yang telah terkumpul yaitu penggambaran dan pemisahan sesuai kategori dengan kata-kata ataupun kalimat untuk memperoleh kesimpulan. ${ }^{12}$ Dalam metode analisis

10 Amiruddin dan Zainal Asikin, 2004, Pengantar Metode Penelitian Hukum, Raja GrafindoPersada, Jakarta, hlm.25.

11 Bambang Waluyo, 2002, Penelitian Hukum Dalam Praktek, Sinar Grafika, Jakarta, hlm. 72.

12 Suharsini Arikunto, 1986, Prosedur Penelitian, Bina Aksara, Jakarta, hlm. 194. deskriptif, untuk memperoleh kesimpulan mengenai permasalahan hukum dalam penelitian ini maka data yang telah dianalisis harus disusun kembali secara sistematis.

\section{HASIL DAN PEMBAHASAN}

4.2 Pengaturan Perlindungan Hukum Terhadap Pegadaian Dalam Hal Barang Jaminan Bukan Milik Debitur

Setiap pemberian kredit harus diikuti dengan suatu penjaminan guna pengaman kredit yang telah diberikan. Dalam pemberian jaminan dapat dibedakan atas jaminan dengan penguasaan benda dan tanpa penguasaan benda tersebut. Bentuk lembaga seperti gadai bagi kreditur lebih aman, karena benda bergerak yang dijadikan jaminan berada dalam penguasaannya. Hak dari pemegang benda jaminan pada gadai bersifat kebendaan, yang memberikan jaminan bagi kreditur bahwa piutangnya pasti dibayar.Memperjanjikansuatujaminan kebendaan, seperti memperjanjikan gadai atau hipotik dan jaminan kebendaan lainnya, pada intinya adalah melepas sebagian dari kekuasaan seorang pemilik (pemberi gadai) atas barang gadai demi, keamanan kreditur yaitu dengan mencopot kekuasaannya untuk memindah tangankan benda itu. $^{13}$

R. Subekti, 1986, Jaminan-Jaminan Untuk Pemberian Kredit Menurut Hukum Indonesia, Alumni, Bandung, hlm. 27 
Untuk sahnya suatu perjanjian gadai, pemberi gadai haruslah seorang yang berwenang menguasai bendanya. Benda itu bisa dipegang oleh kreditur penerima gadai yang selanjutnya disebut sebagai kreditur pemegang gadai atau oleh pihak ketiga, yaitu pihak ketiga pemegang gadai. Karena benda gadai ada ditangan pemegang gadai, maka ada yang menyebutnya sebagai VUISTPAND . Seakan-akan benda gadai ada di dalam genggaman pemegang gadai. Jadi benda gadai pada asasnya ada dalam kekuasaan pemegang gadai. ${ }^{14}$

Apabila pemegang gadai dalam menerima gadai beritikad baik, maka ia memperoleh perlindungan terhadap pemberi gadai yang tidak berwenang menguasai jaminan tersebut. Pengertian dari itikad baik di sini ialah pemegang gadai merupakan pemilik sebenarnya dan hak yang dimiliki oleh pemberi gadai tersebut tidak disangsikan. ${ }^{15}$ Pemegang gadai sebagai kreditur mendapat perlindungan dalam pemenuhan hak - hak atas piutangnya sehingga merasa terjamin.

Dalam upaya untuk membantu penyediaan dana untuk meningkatkan produktifitas atau pendapatan masyarakat yang dapat dinikmati oleh seluruh lapisan, maka tidak jarang ada nasabah (debitur) yang melakukan wanprestasi. Untuk itu

14 J. Satrio, 2002, Hukum Jaminan Kebendaan Fidusia, Citra Aditya Bakti, Bandung, hlm. 9

15 Mariam Darus Badrulzaman, 1999, Bab-Bab Tentang Credietverband, Gadai dan Fidusia, Alumni, Bandung, hlm. 59 hal yang demikian ini pihak PT. Pegadaian (Persero) sebagai kreditur oleh Undang-undang yaitu menurut kitab Undang-undang Hukum Perdata Pasal 1150, diberi kewenangan untuk mengambil pelunasan dari barang gadai, yakni dengan melakukan parate eksekusi. Selain itu pihak PT. Pegadaian (Persero) selama tidak menyalahgunakan barang gadai, nasabah (debitur) tidak berhak untuk menuntut pengembalian barang gadai.

Pengaturan Perlindungan hukum terhadap Pegadaian dan nasabah dapat terlihat dari Perjanjian Utang Piutang Dengan Jaminan Gadai yang ditentukan oleh Pihak Pegadaian pada saat akan memberikan kredit pada nasabah, perjanjian tersebut memuat hal-hal sebagai berikut:

1. Nasabah menerima dan setuju terhadap uraian barang jaminan, penetapan besarnya taksiran barang jaminan, uang pinjaman, dan tarif sewa modal, sebagaimana dimaksud pada halaman depan dan Surat Bukti Kredit (SBK) ini sebagai tanda bukti yang sah penerimaan Uang Pinjaman.

2. Barang yang diserahkan debitur sebagai jaminan adalah benar milik nasabah dan/ atau kepemilikan sebagaimana diatur dalam pasal 1977 KUHPerdata serta menjamin bahwa jaminan tersebut tidak berasal dari hasil kejahatan, tidak merupana obyek sengketa, ataupun sita jaminan. 
3. Nasabah menyatakan telah berutang kepada PT. Pegadaian (Persero) dan berkewajiban untuk membayar Pelunasan Uang Pinjaman ditambah Sewa Modal sebesar Tarif Sewa Modal yang berlaku di PT. Pegadaian (Persero).

4. Dalam hal terjadi kerusakan bencana alam yang disebabkan oleh bencana alam ( force majeure) yang telah ditetapkan Pemerintah, PT. Pegadaian (Persero) akan memberikan ganti rugi. Ganti rugi diberikan setelah diperhitungkan dengan uang pinjaman dan sewa modal sesuai ketentuan penggantian yang berlaku di PT. Pegadaian (Persero).

5. Nasabah dalammelakukan Ulang Gadai, Gadai Ulang Otomatis, Mengangsur uang pinjaman atau minta tambah sewa modal dan biaya administrasi yang masih akan dibayar. Jika terjadi penurunan nilai taksir barang jaminan pada saat ulang gadai dan gadai otomatis, maka nasabah wajib mengangsur uang pinjaman sesuai dengan taksirann yang baru.

6. Apabila sampai dengan tanggal jatuh tempo idak dilakukan pelunasan, penundaan lelang, Ulang Gadai atau Gadai Ulang Otomatis, maka PT. Pegadaian (Persero) berhak melakukan penjualan barang jaminan melalui lelang.
7. Hasil penjualan lelang barang jaminan setelah dikurangi uang pinjaman, sewa modal dan bea lelang merupakan kelebihan yang menjadi hak nasabah. Jangka waktu pengambilan uang kelebihan lelang selama satu tahun sejak tanggal lelang, dan jika lewat waktu dari jangka waktu pengambilan uang kelebihan, nasabah menyataka setuju untuk menyalurkan uang kelebihan tersebut sebagai dana kepedulian sosial yang pelaksanaannya diserahkan kepada PT. Pegadaian (Persero), jika hasil penjualan lelang barang jaminan tidak mencukupii untuk melunasi kewajiban nasabah berupa uang pinjaman, sewa modal dan bea lelang maka nasabah wajib untuk membayar kekurangan tersebut.

8. Nasabah harus datang sendiri untuk melakukan ulang gadai, minta tambah uang pinjaman, mengangsur uang pinjaman, penundaan lelang, pelunasan dan menerima barang jaminan atau dengan memberikan kuasa kepada orang lain dengan mengisi dan membubuhkan tandatangan pada kolom yang tersedia, dengan melampirkan fotocopy KTP nasabah dan Penerima Kuasa serta menunjukkan asli KTP penerima kuasa.

9. Nasabah yang menggunakan layanan gadai ulang otomatis 
membubuhkan tandatangan pada kolom yang tersedia.

10. Nasabah menyatakan tunduk dan mengikuti segala peraturan yang berlaku di PT. Pegadaian (Persero) sepanjang ketentuan yang menyangkut Hutang Piutang Dengan Jaminan Gadai.

11. Apabila terjadi perselisihan dikemudian hari akan diselesaikan secara musyawarah untuk mufakat dan apabila tidak tercapai kesepakatan akan diselesaikan melalui Pengadilan Negeri Setempat.

Perlindungan hukum bagi pihak pegadaian dalam hal barang jaminan gadai bukan milik debitur secara umum pengaturan perlindungan hukum ini dapat dilihat dari ketentuan Pasal 1131 dan 1132 KUHPerdata. Pasal 1131 KUH Perdata pada prinsipnya menentukan bahwa segala kebendaan yang merupakan harta kekayaan si berutang baik yang sudah ataupun akan ada dikemudian hari menjadi jaminan tanggungan segala perikatannya.

Selanjutnya Pasal 1132 KUH Perdata menentukan bahwa, kecuali terdapat alasan yang sah untuk dapat didahulukan, maka kebendaan yang menjadi harta kekayaan si berutang tersebut digunakan sebagai jaminan secara bersama untuk semua orang yang memberi hutang kepadanya. Sehubungan dengan hak kebendaan sebagai jaminan hutang yang dibebankan dengan gadai tersebut, maka pengertian hutang terdapat dua pendirian, yaitu hutang dalam arti sempit dan hutang dalam arti luas. Hutang dalam arti sempit hanya meliputi hutang yang timbul dari perjanjian hutang piutang saja dan hutang dalam arti luas merupakan hutang yang timbul dari perikatan apapun juga, meliputi hutang yang timbul dari hutang piutang, dari Undang-Undang mapupun perjanjian lainnya. ${ }^{16}$ apabila barang yang dijadikan jaminan gadai adalah hak milik orang lain maka pemilik barang yang dijadikan jaminan gadai dapat mengajukan tuntutan hukum pengembalian barang kepada PT. Pegadaian (Persero). Sesuai dengan pasal 1977 ayat(2)KUHPerdata:"siapa yang kehilangan barang atau kecurian sesuatu barang miliknya dengan menunjukan surat bukti dan dengan persetujuan dari pihak pegadaian dapat menuntut kembali bendanya yang digadaikan itu dari pemegang gadai. Jika barang yang dijadikan gadai adalah hak milik orang lain, maka pemilik barang yang dijadikan jaminan gadai dapat mengajukan tuntutan hukum pengembalian barang pada PT. Pegadaian (Persero).”

\subsection{Penyelesaian Sengketa Terhadap Barang Jaminan Gadai Bukan Mili Debitur}

Perjanjian atas gadai bertujuan untuk suatu kepastian dan pemberian

16 Sutan Remy Sjahdeini, 2002, Hukum Kepailitan, Pustaka Utama Grafiti, Yogjakarta, hlm. 115 
jaminan untuk pemenuhan prestasi tertentu, sifatnya adalah mengikuti perjanjian pokoknya perjanjian yang sehingga perjanjian gadai bersifat accessoir. Pada prinsipnya jaminan gadai dapat dipakai untuk menjamin setiap kewajiban atas suatu prestasi. sehingga perjanjian gadai hanya akan ada setelah ada perjanjian hutang piutang sebagai perjanjian pokoknya.

Dalam rangka mengamankan piutang kreditur, maka secara khusus oleh debitur kepada kreditur diserahkan suatu kebendaan bergerak sebagai jaminan pelunasan hutang debitur, yang menimbulkan hak bagi kreditur untuk menahan kebendaan bergerak yang digadaikan tersebut sampai dengan pelunasan hutang debitur. Dengan demikian, pada dasarnya perjanjian gadai akan terjadi bila barang-barang yang digadaikan berada dibawah penguasaan kreditur (penerima gadai) atau atas kesepakatan bersama ditunjuk seorang pihak ketiga untuk mewakilinya. Penguasaan kebendaan gadai oleh penerima gadai tersebut merupakan syarat esensial bagi lahirnya gadai.

Penguasaan terhadap benda bergerak, maka berlaku asas yang diatur dalam pada Pasal 1977 ayat (1) KUHPerdata yang pada prinsipnya menentukan bahwa siapa yang yang menguasai suatu benda bergerak maka ia dianggap sebagai pemilik benda bergerak tersebut. Ketentuan Pasal 1977 KUHPerdata mengandung ketentuan tentang verjaring yaitu extinctieve verjaring dengan waktu nol tahun sehingga bezit benda bergerak diatur dalam buku IV KUHPerdata bukan buku II KUHPerdata.

Terhadap perumusan Pasal 1977 ayat (1) KUHPerdata itu kemudian timbul beberapa macam pendapat yang memberikan penafsiran terhadap kedudukan bezit mengenai benda bergerak sebagaimana tercantum dalam Pasal 1977 ayat (1) BW itu. Ada dua macam pendapat yang terkenal dengan teorinya masing-masing yaitu:

a. Eigendeom theorie

Memberikan penafsiran secara gramatikal terhadap pasal 1997 ayat (1) KUHPerdata dan dikemukakan oleh Meijers. Menurut teori ini bezit terhadap benda bergerak merupakan alas hak yang sempurna dan hak yang paling sempurna adalah eigendom, sehingga eigendom merupakan bezit terhadap benda bergerak (bezitter sama dengan eigenaar).

b. Legitimate-theorie

Dikembangkan oleh scholten yang berpendapatbahwabezit bukanlah eigendom. Menurut teori ini siapapun memerolehkeadaanaman apabiladalam membezit benda bergerak ia beritikad yang baik dan jujur. Jadi keadaan tersebut fungsinya mengesankan bezitter dari benda itu sebagai pemegang hak penuh atau eigenaar. Adanya ketentuan pasal 1977 ayat (1) KUHPerdata dimaksudkan untuk menjaga kelancaran lalulintas hukum di tengah masyarakat jangan sampai terhambat. ${ }^{17}$

Abdulkadir Muhammad, 2000, Hukum Perdata Indonesia, Citra Aditya Bakti, Bandung, hlm. 124 
Pengecualian dari pasal 1977 ayat (1) KUHPerdata termuat dalam Pasal 1977 ayat (2) yang pada pokoknya menentukan bahwa perlindungan yang diberikan Pasal 1977 ayat (1) KUHPerdata tidak berlaku bagi barang bergerak yang yang hilang atau diperoleh dengan mencuri. Bagi subjek hukum yang kehilangan atau kecurian sesuatu barang, maka ia berhak untuk memintanya kembali maksimal tiga tahun sjak hari kehilangan barang tersebut. (hak revindicatie). Pemilik barang tidak diwajibkan membayar ganti kerugian kepada pemegang barang untuk uang yang telah dibayarkan guna membelinya, kecuali barang itu dibelinya di pasar tahunan atau pasar lainnya, di pelelangan umum, atau seorang pedagang yang lazim memperdagangkan barangbarang demikian, pemilik barang harus mengembalikan harga barang yang telah dibayar oleh pemegang abrang itu (Pasal 582 KUHPerdata).

Tujuan gadai memberikan kepastian hukum yang kuat bagi kreditur-kreditur dengan menjamin pelunasan piutangnya dari benda yang digadaikan, jika debitur wanprestasi. Pada saat akan menerima barang gadai, pihak penerima gadai harus teliti dalam melakukan pemeriksaan dan pengecekan atas kepemilikan dari barang yang digadaikan tersebut, karena apabila barang yang dijadikan objek gadai tersebut ternyata bukanlah milik pemberi gadai, maka penerima gadai dapat dituntut oleh pemilik asli barang tersebut dengan tuduhan sebagai penadah dalam kegiatan operasionalnya menerima barang jaminan sebagai agunan kredit di PT. Pegadaian (Persero) berdasarkan Hukum Gadai. (berdasarkan hasil wawancara dengan Ibu Ni Ketut Wiratni, Kepala Unit PT. Pegadaian (Persero) Unit Jimbar Jaya Cabang Renon Kota Denpasar, pada tanggal 1 Pebruari 2015)

Dalam kaitannya dengan penelitian tesis ini, mengangkat kasus yang terjadi pada PT. Pegadaian (Persero) mengenai barang jaminan gadai yang bukan milik debitur, dalam hal ini adalah barang curian. Kasus ini telah mendapatkan putusan dari Pengadilan Negeri Denpasar dengan Nomor Putusan 249/Pid. B/2012/PN.Dps. Menurut pendapat Bapak Ariyanto selaku Pemimpin PT. Pegadaian (Persero) cabang Renon menyatakan bahwa atas putusan yang dijatuhkan oleh Pengadilan Negeri Denpasar ini maka dilakukan Permohonan Penghapusan Barang Polisi UPC. Jimbar Jaya yang ditujukan kepada Pemimpin Wilayah VII, U.P Bagian Bisnis Gadai PT. Pegadaian (Persero) di Denpasar. Permohonan penghapusan ini menunjuk pada putusan Pengadilan Negeri Denpasar Nomor. 249/Pid.B/2012/PN.Dps. atau kasus pencurian barang jaminan yang menjadi obyek Agunan (BJ) di UPC. Jimbar Jaya maka atas putusan tersebutdimohonkan untuk dilakukan penghapusan. Penghapusan ini bertujuan untuk mencegah kerugian 
yang timbul semakin besar seiring berjalannya sewa modal dari kredit tersebut. Hal ini sudah beberapa kali dilakukan terkait dengan barang jaminan merupakan curian ataupun barang jaminan adalah palsu sehingga menimbulkankerugianbagiperusahaan (berdasarkan hasil wawancara yang dilakukan pada tanggal 6 Pebruari 2015 )

Dari uraian singkat tentang contoh kasus diatas dapat diketahui bahwa apabila terjadi barang jaminan gadai bukan hak milik debitur maka penyelesaian hukumnya di Pegadain adalah pihak pegadaian terlebih dahulu harus ada laporan dari pihak yang dirugikan yaitu pemilik barangnya sebenarnya. Pemilik benda gadai yang merasa kehilangan barang, dapat menuntut kembali bendanya yang digadaikan itu dari pemegang gadai dengan memperhatikan batas waktu untuk menuntut kembali. Apabila pemilik telah kehilangan kekuasaan atas benda tersebut, pemilik dapat menuntut kembali bendanya yang telah digadaikan itu dari pemegang gadai dengan jangka waktu tidak lebih dari 3 tahun sejak kehilangan atau di curinya benda miliknya. Pemilik barang tersebut untuk dapat mendapatkan kembali barangnya harus menempuh prosedur hukum dengan membuat laporan kehilangan ke kantor polisi. Hingga bisa diproses lebih lanjut di Pengadilan. Biasanya dalam proses penyidikan bukti - bukti termasuk barang jaminan gadai akan disita oleh pihak kejaksaan. Bagi jaminan gadai yang merupakan hasil curian disita sebagai bukti di pengadilan dan bagi jaminan gadai palsu disita dan dirusak bentuknya sebagai pembuktian bahwa jaminan tersebut adalah palsu. Sejak tahun 2000 ke atas kasus seperti ini makin marak sehingga menyebabkan kerugian yang tidak sedikit bagi Pegadaian.

\section{PENUTUP \\ 4.1 Simpulan}

1. Pengaturan mengenai perlindungan hukum terhadap PT Pegadaian (Persero) dalam hal barang jaminan gadai bukan milik debitur yang diperoleh secara melawan hukum sesuai dengan ketentuan pasal 1977 ayat 1 KUHPerdata yang pada prinsipnya menyatakan bahwa orang yang menguasai benda tersebut dianggap sebagai pemiliknya serta bukti Surat Bukti Gadai poin dua yang menyatakan bahwa barang jaminan yang diserahkan adalah milik nasabah atau kepemilikan sesuai pasal 1977 KUHPerdata dan jaminan barang tersebut bukan hasil kejahatan, sengketa ataupun sita jaminan.

2. Penyelesaian hukum atas barang jaminangadaibukanmilik debitur maka pemilik benda gadai yang merasa kehilangan barang, dapat menuntutkembalibendanyayang digadaikan itu dari pemegang gadai dengan memperhatikan 
batas waktu untuk menuntut kembali. Pemilik yang telah kehilangan kekuasaan atas benda tersebut,maka pemilik dapat menuntut kembali bendanya yang telah digadaikan tersebut dari kekuasaan pemegang gadai dengan jangka waktu maksimal 3 tahun sejak kehilangan atau di curinya benda tersebut. Pemilik barang tersebut untuk dapat mendapatkan kembali barangnya harus menempuh prosedur hukum dengan membuat laporan kehilangan ke kantor polisi hingga bisa diproses lebih lanjut di Pengadilan.

\subsection{Saran}

1. Kepada Pemerintah dalam hal ini sebagai pembentuk peraturan hendaknya segera membuat suatu undang-undang yang khusus mengatur mengenai gadai. Karena sampai saat ini belum ada undang-undang khusus yang mengatur mengenai gadai. Pembentukan undangundang ini diharapkan lebih memberikan jaminan kepastian dan perlindungan hukum bagi para pihak yang terikat dalam perjanjian gadai.

2. Bagi PT. Pegadaian (Persero) hendaknya lebih berhati-hati dalam melakukan penaksiran atas barang jaminan, sehingga sebelum memberikan kredit gadai dapat dipastikan bahwa barang yang dijadikan jaminan tersebut memang benar-benar milik si calon debitur sehingga tidak akan terjadi permasalahan dikemudian hari.

\section{DAFTAR PUSTAKA}

Abdul Kadir Muhammad, 2000, Hukum Perdata Indonesia, PT Citra Aditya Bakti, Bandung

Abdulkadir Muhamad, 2004, Hukum dan Penelitian Hukum, Citra Aditya Bakti, Bandung

Amiruddin dan Zainal Asikin, 2004, Pengantar Metode Penelitian Hukum, Raja GrafindoPersada, Jakarta

Bambang Waluyo, 2002, Penelitian Hukum Dalam Praktek, Sinar Grafika, Jakarta

Edy Sasmito, dkk, 2010, Pegadaian dan rakyat kecil, IPB Pers, Bogor

J. Satrio, 2002, Hukum Jaminan Kebendaan Fidusia, Citra Aditya Bakti, Bandung

Mariam Darus Badrulzaman, 1999, Bab-Bab Tentang Credietverband, Gadai dan Fidusia, Alumni, Bandung

R Subekti, 1982, Jaminan - Jaminan Untuk Pemberian Kredit Menurut Hukum Indonesia, Alumni, Bandung

R. Subekti, 1986, Jaminan-Jaminan UntukPemberian KreditMenurut Hukum Indonesia, Alumni

Sri Soedewi Masjchocn Sofwanf,2000, Hukum Perdata Hukum Benda, Cet. V, Liberty, Yogyakarta 
Suharsini Arikunto, 1986, Prosedur Penelitian, Bina Aksara, Jakarta

Sutan Remy Sjahdeini, 2002, Hukum

Kepailitan, Pustaka Utama Grafiti, Yogjakarta.

\section{Majalah:}

Warta Pegadaian, edisi 160/tahun xxiii/2012.

Warta Pegadaian, edisi 161/tahun xxiii/2013.

\section{Internet :}

TriniHandayani, Penguasaan Benda (BEZIT), http://trinihandayani. wordpress.com/2010/05/20/ penguasaan-benda-bezit/, diunduh pada 20 Juli 2014 